\title{
Creating a Pastoral World Through Fire: The Case of the Manawatu, 1870 - 1910
}

\author{
CATHERINE KNIGHT
}

\begin{abstract}
This article examines the role of bush burning in the opening up of bush country in the Manawatu for pastoral farming. Within only a few decades, bush burns had transformed a densely forested environment into one of verdant pasture, scattered with the charred stumps and limbs of incinerated forest. The paper explores the perceptions of bush burning at the time, before examining the voices of doubt and dissent in respect to the rapid destruction of New Zealand's native forest, both at a national and local level. Finally, the paper will seek to explain why, compared in particular to the South Island, the local voices of protest were only weak, and failed to lead to any effective action (political or otherwise) to preserve Manawatu's forests.
\end{abstract}

\section{Introduction}

When the Manawatu, in the lower North Island of New Zealand, was opened up for European settlement in the late $1860 \mathrm{~s}$, it was almost completely clothed in thick, impenetrable forest. There were no roads or railways; the Manawatu River and a few Māori bush-tracks were the only means of access into this forested hinterland. ${ }^{1}$

Initial settlement was slow, and several years after its purchase by the Government, The Official Handbook of New Zealand described the district as having 'an almost inexhaustible supply of the most valuable sawing timber.' But within 30 years, with the aid of the FoxtonWanganui railway, completed in 1878, and a network of privately-owned bush tramways, most of the easily accessible and marketable timber had been milled, and the settler farmers had moved in to clear the remaining bush from their newly purchased blocks of land. ${ }^{2}$

It was this next phase in the process of 'breaking in the wilderness' - bush burning - that was to prove the most destructive to the Manawatu's once majestic forests; eventually decimating all but small remnants of the forest which once covered the region's plains, valleys and hills. As Pyne (1997) vividly puts it: 'Railroads cracked open sealed woods, and fires scurried through the fissures.' In place of the forest, pasture (initially littered with charred stumps and tree limbs) made its steady advance across the terraces, valleys, hills and, finally the swamplands. Sheep-farming at first dominated inland Manawatu's agricultural landscape, with only small herds of dairy cattle kept for domestic use and local sales. ${ }^{3}$

This clearance of the Manawatu's forests took place within the wider context of the transformation of the lower North Island, on land newly acquired from Māori. From the 1870s to the 1910s, an enormous zone of bush was cleared in the southern regions of the North Island - the biggest such clearance in the country's history. In his historical geography of New Zealand, Grey (1994) estimates that the land cleared in the North Island in the 12 years from 1874 and 1886 alone was likely to be about 328,000 hectares - about one-quarter of the area newly occupied by European settlers. ${ }^{4}$ As McKinnon et al (1997) point out, the clearance was questioned, if at all, for its too rapid destruction of a valuable resource, rather than for the process itself. ${ }^{5}$ It was to have almost immediate environmental consequences - in the form of erosion and floods - which are still evident in the region today. ${ }^{6}$

It also meant that, when, 100 years later, local historian Ian Matheson wrote his centennial history of Palmerston North, he noted how a resident needed to travel 40 kilometres to experience lowland forest. Matheson describes this as 'a sad commentary on the foresight of our pioneers'. ${ }^{7}$ While many today would agree, this judgement is made from the perspective 
gained from the distance of time, and from a position of relatively comfortable lives, but one which fails to take into account the vastly different conditions - social, economic, and environmental - of the time. For these settlers, the removal of the bush was an unquestioned pre-requisite to making a living from the land, and for many, a condition of the deferred payment schemes under which they purchased their land. This judgement also fails to take into account the unforgiving and imprecise nature of the tool widely employed to clear the forest fire.

This article will first examine the way in which fire was used by European settlers in the Manawatu, and its geographic and temporal occurrence. It will then discuss the perceptions of bush burning at the time, before examining the voices of doubt and dissent in respect to the rapid destruction of New Zealand's native forest, both at a national and local level. Finally, the essay will seek to explain why, compared in particular to the South Island, the local voices of protest were only weak and never led to any action (political or otherwise) to preserve Manawatu's forests.

\section{'Breaking In' Manawatu's Forested Hinterland}

By the second half of the nineteenth-century, much of the 'open country' in regions such as Canterbury, Otago and Hawkes' Bay had been settled, often in large estates or sheep runs, well beyond the means of the working-class man. ${ }^{8}$ From the 1870 s, the Government turned its focus to the provision of land for the settlement of those of lesser means; the 'small man'. 9 This impetus only strengthened when, in the 1880 s, the frozen meat trade became established, making small sheep farms viable. ${ }^{10}$ Large areas of the North Island remained in Māori ownership in the latter half of the nineteenth century. These lands were still forested and undeveloped, and referred to as 'waste lands' in the official language at the time. ${ }^{11}$ One such region was the Manawatu.

In the Manawatu too, it had been the relatively open country of the coastal area around the mouth of the Manawatu River that was settled first, initially by whalers and traders, and subsequently by the New Zealand Company in an ill-fated land purchase in 1841 that eventually contributed to the Company's downfall. The coastal Awahou block was later purchased by the Crown in 1859. However, the block was relatively small and included none of the great tracts of forested land of inland Manawatu. It was to the latter that the Government next turned its sights, purchasing this area in two large blocks, the Te Ahuaturanga (or Upper Manawatu) block in 1864, and the Rangitikei-Manawatu block in 1866. Together, this was an area comprising about 450,000 acres, stretching from the Rangitikei River in the north to the foot of the Tararua/Rangitikei Ranges in the south, and to the Tasman Sea in the west. ${ }^{12}$ 


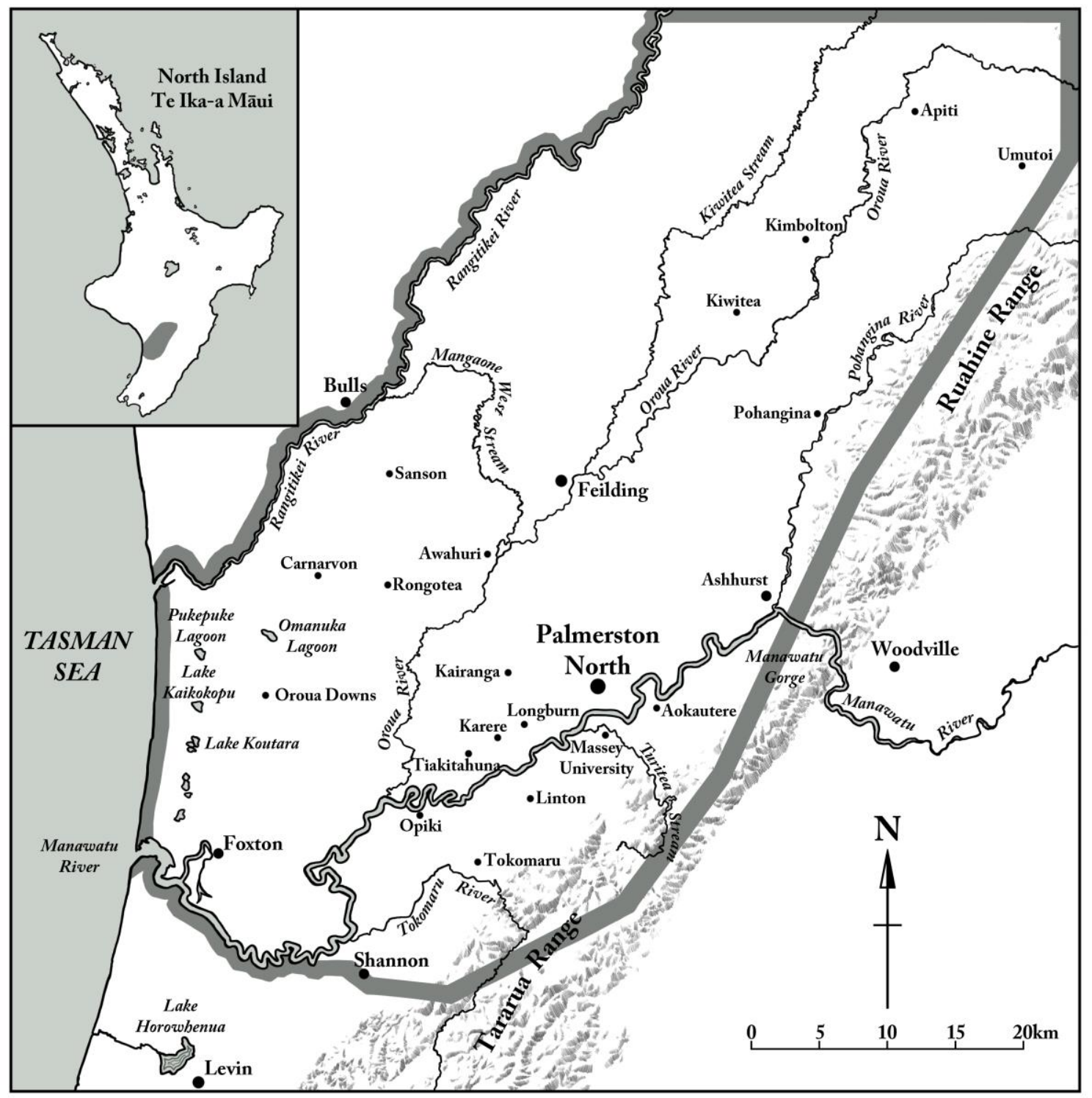

Figure 1: Map of the Manawatu region as defined for the purposes of this research, showing locations mentioned in the text. 
Within these blocks, the towns of Palmerston North, Feilding, Kimbolton, Ashhurst and Pohangina were eventually established.

The first inland Manawatu town (Palmerston North) was not subdivided and made available for sale until 1866, and initial sales were slow. It is likely that bush burning did not begin in earnest until the 1870s, after the easily exploitable timber was removed and milled. From a survey of local papers - and taking into account limitations of this method - bush firing appeared to be most common from the 1870 s through to the 1880 s, tailing off by the late $1890 \mathrm{~s}$, when most land had been 'broken in'. ${ }^{13}$ By the early-twentieth-century, bush burning was becoming a less common occurrence, particularly around large towns. A 1906 farming column in the Feilding Star, for example, reminisces about the quality of the hoggets that 'came off a new burn', but notes that 'burns are things of the past in this district.' 14

Newspaper coverage reveals a clear geographical movement in the bush-burning 'frontier', the frontier radiating out from the earlier established towns, and reaching out to the more sparsely populated areas in the east toward the end of the century. Thus, reportage on burnings in and around settlements such as Palmerston North, Feilding, and later, Ashhurst, predominate in the 1870s, 80s and early 90s, with more outlying districts, such as Apiti and the Pohangina Valley, predominating in the late 1890s and early years of the twentieth-century. ${ }^{15}$ Depending on the direction of the wind, some of these more outlying fires could still affect town-dwellers. As late as 1908, Palmerston North was on occasion enveloped by smoke from bush fires around the Manawatu Gorge (about 20 kilometres distant). One account mentions 'smoke so thick that it was impossible to see across the Square'. ${ }^{16}$

The clearance of bush from farmland was not seen simply as necessary for bringing land in to production and, therefore, making a living off the land, it was also a condition of the deferred payment scheme under which many settlers purchased their land. Under the Land Act 1877 , the settler was able to repay the outstanding amount for the land, provided he lived on the land and made 'improvements', in other words, cleared the bush and sowed pasture. ${ }^{17}$ Under the Act, deferred-payment schemes were offered to encourage small 'family' farms the maximum block was 130 hectares, about a quarter of the average sheep or sheep and beef farm today. ${ }^{18}$

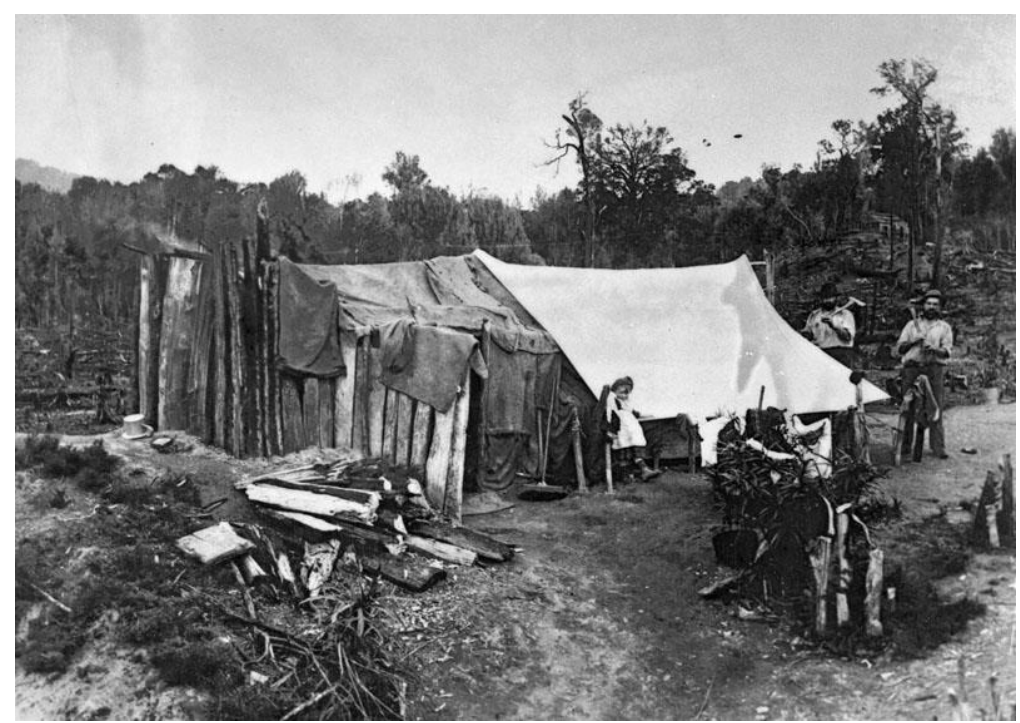

Figure 2: A Manawatu settler's first home. Palmerston North City Library. 
An entire farm was not cleared and sown in one season. The usual pattern was to burn and sow only a portion of the property in the first year and then to gradually 'break in' the remaining land over a period of five or 10 years. In this way the property provided the farmer with a means of subsistence while further clearance was taking place. In his history of Kairanga, Mildon (1989) found that excepting areas of contract felling, where large tracts would be felled and burnt at one time, the practice of the settlers in the Kairanga block, west of Palmerston North, was to clear their boundary fence lines, then up to 20 acres of bush per year. Working from the front of their section, the settlers would bring their farm into production by stages. In parallel, they would supplement their income through contract work such as road building, ditch digging or contract bush felling. ${ }^{19}$

While bush burning could be large-scale and carried with it significant risk, it was far from indiscriminate. Many months of work went into preparing for a 'good burn', and the farmer had to wait until the right weather conditions before 'firing up'. To be successful, a burn needed to be preceded by about six weeks of dry weather, and on the day required a strong breeze in the direction desired for the burn. ${ }^{20}$ Burn-offs were usually undertaken in the summer or early autumn - March commonly being seen as the optimal month in the Manawatu. Because the weather conditions required for a successful burn were quite limited, in some cases, two or more years would pass before a settler farmer could attempt a burn.

Before a burn was undertaken, the bush needed to be prepared through a labour-intensive process of bushfelling. Bush felling usually took place in the winter months so that the vegetation could then be left over the summer months to dry out in readiness for the burn. Landowners generally contracted the work out to bushfellers (otherwise known as bushmen, or 'bush-whackers').

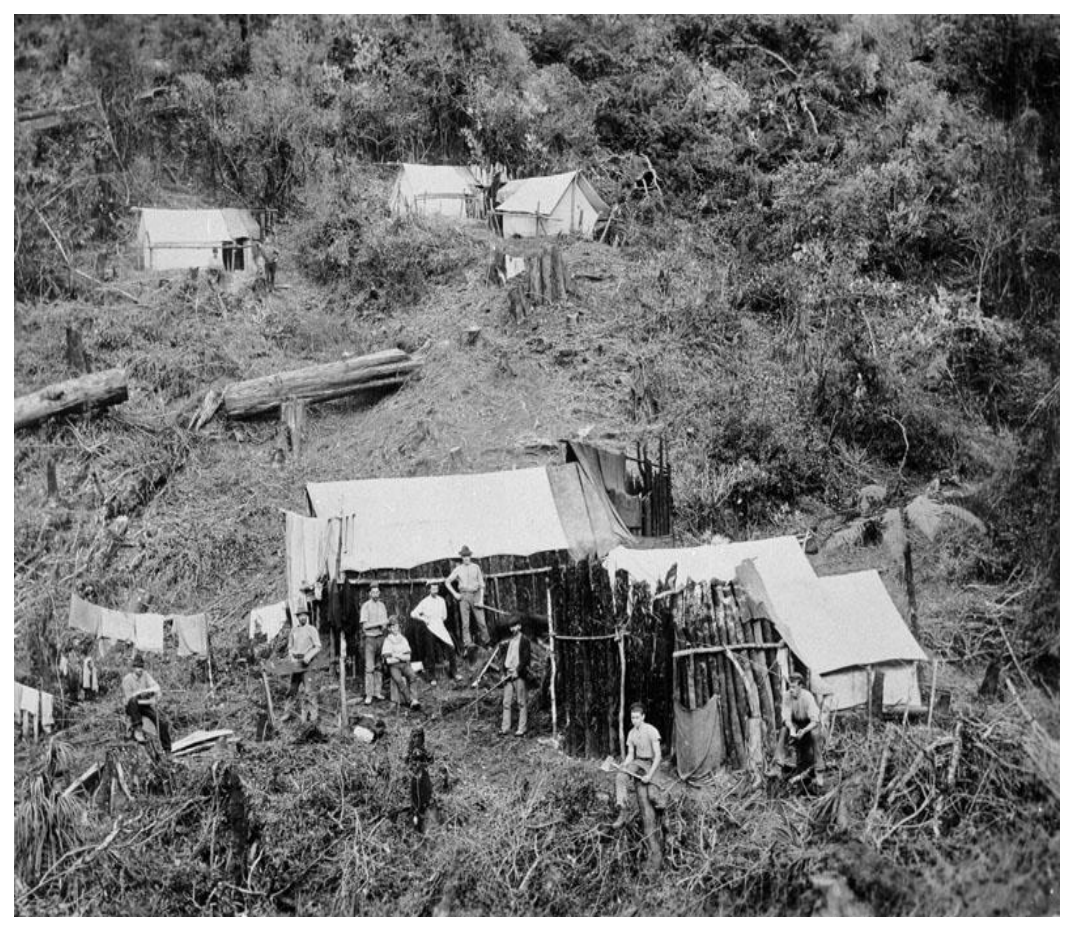

Figure 3: Bush-whackers' camp in Komako, Pohangina Valley, circa 1904. Palmerston North City Library. 
Those who engaged in bushfelling work were sometimes itinerant labourers who owned no property in the district, but often they were local farmers who found it necessary to supplement their income by felling bush on a neighbouring farm. ${ }^{21}$

The first phase of bushfelling was 'underscrubbing'. This involved cutting down the dense understory of the forest with axes or slashers. The understory vegetation was left on the ground to dry over the summer months, later becoming fuel for the 'burn off'. The bushfeller would then cut the upper story of the forest, using an axe or saw, depending on the height, size and type of tree. An alternative technique was known as the 'drive', where several large trees standing in an approximate line were partly cut (scarfed) on one side and then a driver tree felled, setting in motion a line of falling trees. ${ }^{22}$

Settlers were advised to get their bush felled properly, as a good bush felling was critical to a 'clean' bush burn. A 'clean' burn left little but the tree stumps and large logs remaining the rest having been incinerated, leaving a thick layer of ash. If the bush did not burn cleanly, much of the vegetation would be left intact, requiring the farmer to either repeat the burn in a few years time (thereby losing the opportunity to productively use the land for that length of time) or undertake 'logging up', a labour-intensive process of piling the unburnt logs and branches into large heaps for later burning.

Given how critical a 'good burn' was to getting land into production quickly and economically, settler farmers were advised not to economize on the contracting of bushfelling services. For example, a visitor to the Wellington and Manawatu regions, reported in the Feilding Star in 1891, warned against the temptation of accepting the lowest tender for bush felling:

When a man wants a block of bush felled he generally calls for tenders, and by the majority the lowest tender is usually accepted. This is often bad policy, as the chances are that the lowest tenderer has to 'slumick' the bush in order to make a reasonable wage. There is nothing worse for the firing of the bush than to have it badly felled, or, as they call it, 'slumicked'. 'Slumicking' is an easy matter, and, worse still, it cannot be noticed as a rule until the bush has began to dry; then, that which has not been cut can be easily detected. So that it will be seen that to pay the bushman a fair wage and have your bush felled properly pays the best in the end, for, as all farmers know there is nothing like a clean burn. ${ }^{23}$

Bush felling contractors also emphasized this point in their advertising. For instance bushfelling contractor, T. Mitchell, proclaimed in his advertisement in the Feilding Star that 'bush properly felled will burn well,' and an article in the same paper advised that 'settlers desirous of having their bush cleared by the most competent men' should make use of the Bush Fellers Union. ${ }^{24}$

Settler farmers aimed to burn off the felled bush on their land as soon as it was sufficiently dry, so that they could sow seed for pasture and put stock on to the land as quickly as possible. The following extracts from Manawatu papers give a sense of the urgency with which this task was perceived by the pioneering farmers and their communities, and how settler farmers' livelihoods depended on it. In 1885, the Manawatu Standard reported that:

Many of the settlers around Ashurst are almost in despair on account of the protracted wet weather. Some of them have had their bush down two years, and have never had a chance to burn. They want to get cattle on their land, so as to get a return for their outlay, but owing to the unprecedented prevalence of rain, they have been unable to burn. Several of them are getting very disheartened with the adverse seasons that have so retarded their operations, and interfered with their progress. ${ }^{25}$

Later that same month, a Kiwitea respondent to the same paper warned that: 
... if the bad weather continued much longer, the settlers who have bush to burn will be great losers. Some hundreds of acres have been felled this year, and there is a large quantity left unburnt from last year. A few weeks of dry weather are much needed to render the bush fit for fire. ${ }^{26}$

In 1891, the Feilding Star reported of Birmingham (today known as Kimbolton) that: ... the weather during the summer has been bad; having a depressing effect on the farmers generally; very much so on those who have bush to burn, and whose very living depends on getting stock on their land. ${ }^{27}$

During the 1880s and 1890s, Manawatu papers often reported on 'good' and 'bad' burns, and give a clear sense of how the 'luck of the burn' was pivotal to the prosperity and wellbeing of a family or community. For example, Ashhurst and Feilding farmers were blessed with 'good burns' in the autumn of 1883, as reported by the Manawatu Times:

We notice that the settlers along the Ashurst and Taonui roads have had some good bush burns this season. On Mr Pleasant's land, where he purposes at once building and settling, there are patches of about half an acre in extent on which there is scarcely anything left but a few stumps, while Messrs Andrew and Garlic have had a burn of about 80 acres, the fire on which has made an exceptionally good clearing. ${ }^{28}$

However, others were less lucky, often in cases where a burn caught the bush on another neighbouring farmer's property, causing it to burn before it was sufficiently dry. This was the case for an Ashhurst farmer in December 1889:

The fire which passed through Mr Warne's felled bush has done considerable damage, a few places are burnt off clean but most of the ground is only cleared of leaves, and some years must elapse before the land will be in as good order as it would be in one season, after a good burn. ${ }^{29}$

The clearing of the bush by burning was a relatively inexpensive and readily accessible method of clearing the land, and was therefore the most favoured method of clearance of the densely forested Manawatu (and throughout much of the North Island). However, it also carried with it significant risks - both to the landowner himself and to his community. A change of the wind often caused the fire to spread on to neighbouring properties, destroying fences, houses and livestock, and endangering the lives of settlers. People became particularly sensitive to the risk of fires catching and spreading following the disastrous fires in Taranaki and western Hawke's Bay of 1885-86, which destroyed houses, businesses, farms and thousands of acres of bush. ${ }^{30}$

The very conditions that made a burn-off successful also increased the risk of it spreading to neighbouring farms or communities; a dry summer would make nearby standing bush tinderdry, and it was not uncommon for fires to get out of control, engulfing homes, sheds, buildings and even bridges. For instance, in February 1885, a bush fire in Bunnythorpe was reportedly caused by a settler 'firing up' without notifying his neighbours. ${ }^{31}$ The Manawatu Standard reported that 'the fires have been most disastrous to Messrs Pascal and others who will be heavy losers, through having to log up, as their bush was not fit to burn'. ${ }^{32}$ In the same month in 1888, the town of Feilding became surrounded by bush fires when an unexpected breeze caused a fire to get out of control. The Feilding Star reported that it 'took its rapid course in the direction of the Kiwitea stream, clearing everything before it, and the bridge on Kimbolton road was several times ignited. Fortunately plenty of water was at hand, so that was saved'. ${ }^{33}$

Bush burns were not always deliberately lit; they were sometimes set off by a burning match carelessly thrown into the scrub, or a spark from the nearby railway. For instance, a fire 
in 1900 was caused by a spark from a passing railway engine, and burnt 50 acres of fallen bush at Heatherlea, near Foxton. This was far from a rare occurrence in the Manawatu region; farmers complained that sparks from railway engines were putting their properties in constant danger. ${ }^{34}$ Local papers provided farmers with advice in an effort to prevent such accidental conflagrations, including the mowing and removal of dry grass growing near homesteads or alongside fences. ${ }^{35}$

Despite the dangers of fires, the outcome of a successful burn was seen both by the landowner and the community as a whole as being worth the risk, and by and large the risk was accepted as part of the path towards achieving a thriving agricultural economy. A successful burn enabled the farmer to sow seed immediately, and potentially to get stock onto the new pasture by the winter. ${ }^{36}$ There was no need for the farmer to clear logs or stumps from the land immediately because sheep and cattle were able to graze among them, and over a number of years, many of the logs decayed and rotted away. Generally, only the stumps of the larger trees remained intact, and had to be removed before the paddock could be ploughed. ${ }^{37}$ Until recently, some parts of farms in areas such as Kairanga had never been ploughed, so the depressions created by decayed or removed tree-stumps and the traces of ancient stream beds were still evident. ${ }^{38}$

The particulars of how soon after the burn sowing should be undertaken was the topic of considerable discussion in newspaper articles and correspondence, but it was generally understood that the layer of ash left by a burn-off created a highly fertile seed-bed. The ash contained nutrients mineralized by the burn and the first season of grass or crops usually showed good growth. While some thought it was best to wait for a few good rains before sowing, farmers were generally advised to sow grass or crops immediately ('as soon as the ash is cool') to take advantage of the fertility. ${ }^{39}$ Another reason often cited for sowing immediately after a burn was that it prevented the invasion of undesirable plants such as manuka, fern, bidibidi and exotic weeds such as scotch thistle. ${ }^{40}$

The grass seeds most commonly sown were ryegrass, dogstail, and cocksfoot, and grass seed was often harvested from the pastures for a few years before they were grazed. ${ }^{41}$

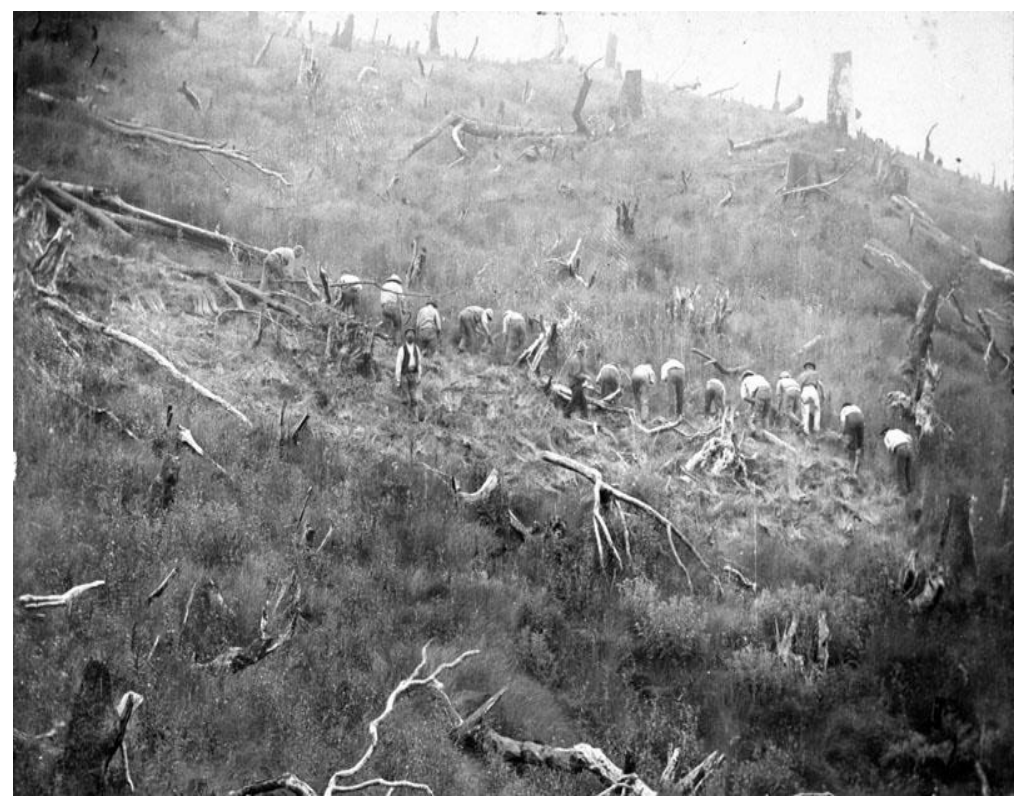

Figure 4: Men reaping grass seed from a farm in Pohangina Valley, 1904.

Palmerston North City Library. 
As the initial fertility declined, fern and scrubby weeds invaded the oversown pastures. Further burning was sometimes undertaken to remove the logs and stumps left after the first burn (particularly when it had not been a particularly 'clean' one), and to clear the regrowth of fern, scrub or weeds. ${ }^{42}$

It was sometimes many years before the final evidence of the long-vanquished forest was finally removed.

The process of removing tree stumps that remained after a burn was termed 'stumping', and often occurred several years after the original burn. The smaller stumps could be levered out with a 'stumping jack', but many of the larger stumps required the use of horses, bullocks or traction engines. When the stumps in one paddock had been hauled out, they were grouped together and burned. ${ }^{43}$ Later, gelatine explosives were used, which shattered the stump into small pieces, thereby obviating the need for burning. ${ }^{44}$

The foregoing section has described the 'mechanics' of bush burning: the process itself, its geographical and temporal occurrence, and the role it played in the development of the farming economy in the Manawatu. The following section will explore the contemporary perceptions of bush burning among the Manawatu community, before examining the response to forest destruction, particularly by burning, at both the national and regional level, and the call for better policy for the preservation of New Zealand's indigenous forests.

\section{Perceptions of Bush Burning in the Manawatu}

Like many elements of our environmental history, attitudes towards bush burning were complex and sometimes contradictory. On the one hand, it was widely seen as a necessary (albeit not entirely unregrettable) step towards making productive use of land and contributing to a burgeoning regional economy. On the other, there were concerns about its wastefulness: that it was literally burning away a valuable resource without allowing for future needs. While town dwellers demonstrated a significant level of tolerance in relation to bush burns, newspaper reportage and correspondence towards the end of the century does reveal what appears to be the emergence of an 'urban-rural divide' in respect to the practice. This section draws on newspaper coverage and settler accounts of bush burning to examine contemporary perceptions and discourse on the practice.

One of the earlier - and often quoted - descriptions of the dramatic scene created by bush burns is an 1877 account by the editor of the Manawatu Times of the burn-offs that were taking place around Palmerston North at the time. This description reveals ambivalence about the burn-offs, and regret for the passing of the indigenous forest; but the prevailing sense is one of resigned acceptance that the destruction of the forest is a necessary step in the path to prosperity and progress:

The smoke that encircles our township by day and the lurid flames by night tell of the advent of March, the month fatal to our sylvian giants. Huge gaps are being made in the bush and from almost every point of the compass may be seen arising columns of smoke spreading themselves in fantastic cloud wreaths, and not infrequently descending upon the town itself. From this it appears that our settlers are availing themselves of the privileges of the season, and although the smoke may inconvenience us and the charred avenues offend the eye, we must accept all thankfully as a mark of local progress. We understand that the process of logging up has been going on with vigor during the past several months, and that many of the fires visible are intended to achieve the final clearing preparatory to the work of culture. ${ }^{45}$

Generally, burn-offs were reported with a strong sense of the 'spectacle' they created for town-dwellers, such as the following accounts of fires in the 1870s and 1880s: 
On Saturday, the country around the town seemed perfectly aglow with bush fires, while the atmosphere was most oppressive. The murky appearance of the sky, and the dull, muggy sensation experienced reminded one forcibly of the bush fires and hot winds of Australia, and as night closed in, the scene became grandly picturesque. On one side the glare of the flames lit up the heavens; while on another, the fire being only in an early stage, was to be seen sparkling here and there through the foliage of the trees, giving the appearance as if the bush hung with countless Chinese lanterns while again the bare and scorched limbs, twined in fantastic shapes, formed a weird foreground to the illuminated sky. ${ }^{46}$

The bush fires in the Fitzherbert district presented a gorgeous spectacle in the darkness last night. Vast dense volumes of smoke rolled upward, illuminated by the flames, giving a grand, though weird appearance to the hills. The fires quite lighted up the surrounding country. We should imagine a good burn should be the result. ${ }^{47}$

When stumps and fallen undergrowth was being burned off the Fitzherbert hills the sight was a fascinating one. The whole of the hills twinkled with lights to give the appearance of a city at night just as one now sees Wellington. ${ }^{48}$

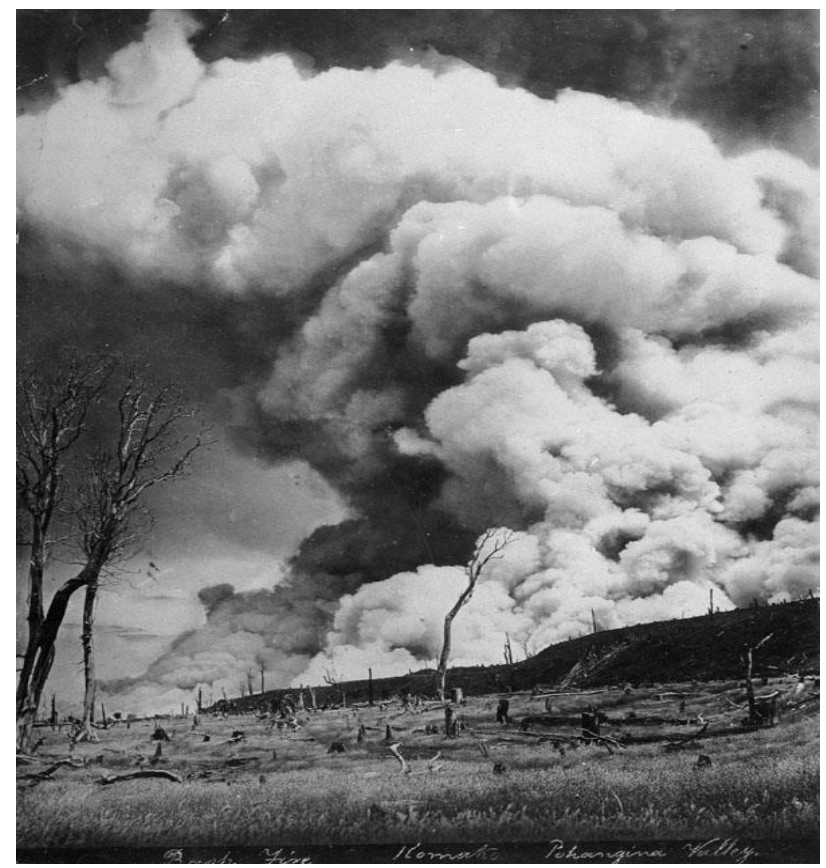

Figure 5: A bush burn in Pohangina Valley, 1904. Palmerston North City Library.

Generally, reportage on burns was supportive of the farming community's endeavours. The following report of 1891, for instance, reveals resolute support for the farmers in their quest to carve out better lives for themselves, even if it meant temporary inconvenience and discomfort for town-dwellers:

We have suffered so that others might gain. For the last few days the town and surrounding district has been smothered in smoke, the dry weather this week having tempted those who had bush to burn, to fire it. As a good burn means a future large expenditure in logging up, fencing, and grass seed sowing, we must all hope that good fortune will follow the efforts of the pioneers. ${ }^{49}$ 
However, the following editorial later in the decade, while in itself supportive of the farming community, alludes to what may be an emerging fissure between the limits of tolerance of town-dwellers, and the aspirations of the farming community:

It is very much the fashion among people who live in towns and who, therefore, have a very limited knowledge of things appertaining to country life to blame settlers on bush land for the recurrence of these destructive fires. After the calamity is past, and the settlers are looking wistfully over many acres of land blackened by the fires and wondering what the other consequences may be, these quid nuncs, in their supposed wisdom, point out how easy it would have been for them (the settlers) to have combined together, pulled the stumps out of the ground, rolled all the logs together and made potash of them. Quite so. All of these things are easy - especially to those who have never attempted them. They forget, if they ever knew, that bush farmers have to make a living off their land as soon after the 'first burn' as possible, and many things have to be done in the way of house building and fencing before the luxury of 'logging' can be indulged in. We have on our part the greatest respect for men who have made bush farms. ${ }^{50}$

Meanwhile, in the neighbouring district of Wanganui, this light-hearted report in the Feilding Star also reveals what is potentially a widening gap in knowledge between the town and rural-dweller as the turn of the century approached:

An up-river settler at Wanganui wrote to his sister acquainting her with the prospects of the new name he was carving out for himself, adding that he was in 'fairly good health, but was sorry to state that recently he had a very bad burn'. By return post he received a roll of bandages, together with a bottle of liniment and full directions for use. $^{51}$

Some of the later reports also reveal some sense of resentment - albeit only in respect to the discomfort and inconvenience caused by the fires - rather than a wider environmental concern of any kind - as exemplified by this 1889 report:

The Foxton residents who have purchased properties at Heatherlea, have very little consideration as to which way the wind blows. For the last week the wind has been near south and what smoke has been raised over there has swept over the township, without improving the comfort or prospects of the inhabitants. ${ }^{52}$

Beyond concerns about their own discomfort and inconvenience as a consequence of fires, some accounts and commentary of the time do reveal a sense of unease over the wholesale bush clearance taking place in the Manawatu and elsewhere. However these concerns too are generally utilitarian in focus. For instance, a small number of correspondents express concern about the scale and rapid pace of forest destruction, and the ability of the district's residents to provide for future timber needs. This comment from a Pohangina correspondent to the Feilding Star in 1890 is typical:

We are looking out to be smothered in smoke for a spell as soon as the bush fires are started. There was one fire up the river the other day when a medium burn was made. However, if clearing goes on at its present pace, in a few years there will be no bush to burn, and the settlers will have to start growing blue gums for firewood and fences. ${ }^{53}$

Another concern that becomes prevalent from the late nineteenth century, most likely influenced by the American scholar George Perkin Marsh's seminal tome Man and Nature, published in 1864, was the exacerbating effect that forest clearance appeared to be having on 
floods and erosion. In his history of the Manawatu, published in 1903, journalist and historian T.L. Buick neatly expressed the flooding risk and its connection with deforestation:

The [Manawatu] river thus deriving its supplies from such a large area, and from so many extended sources with such widely different weather aspects, is naturally subject to periodical and heavy floods, which have been considerably intensified since the denudation of the forest began, and the question of re-foresting the upper portions of the ranges about the head waters of the river and its principal affluents will no doubt arise in the future. ${ }^{54}$

However, not all subscribed to this theory that worsening floods were linked to bush clearance. A.G.S. Bradfield (1892-1964), a local historian with first-hand memories of the bush fires, expressed his dissension towards this view:

... it is difficult to believe that the destruction of the bush has been such a factor as many want us to believe. It may have some bearing but one has only to look at the violent changes that have taken place in the course of the Manawatu River over the centuries to realize that there must have seen some terrific floods in the past far exceeding any that have been experienced since the coming of the white settlers with their axes. The violent changes are indicated today by the numerous old water courses and lagoons that were once part of the river. ${ }^{55}$

It would be a mistake too to conclude that early settlers were oblivious to the aesthetic beauty of the indigenous forest that, at least for a time, surrounded them. In her account of settler life in the Manawatu in the 1880s and 1890s, Charlotte Warburton's description of the forest clearly shows an appreciation of its beauty and even its ecological and hydrological function, hinting too at the influences of Man and Nature:

The fine forest trees, which so heavily clothed the surrounding country, charmed and fascinated the new arrivals in the Manawatu. In writing to their relations at Home they told of the lovely bush smell. The ferns, mosses, trees and damp earth, protected by the layers of leaves through which the trees grew. These leaves held the water after rain as a sponge and let it gently soak through to lower levels and so on to the creeks and rivers. In due season there were all the lovely flowering trees and shrubs; in the Springtime the clematis with its starry flowers, hung gracefully from the branches of trees and on sunny slopes masses of the golden kowhai gave gleaming light to the hill sides and to the fringes of the bush. Later on in the summer the dark green of the taller bush was relieved by splashes of colour from the red rata. The Manawatu Gorge particularly was a glowing sight as there were many ratas on the sides of the hills. There were, in some places, good stand of nikau palms, their coral coloured fruit was very decorative, particularly in the Autumn. The aromatic scent of the shrubs of the dense undergrowth such as tarata or lemon wood and in more open places the manuka was all very pleasant. ${ }^{56}$

Few descriptions of bush burns at the time give any hint of regret about the loss of the forests or the birds and other animals that inhabit it. One of few commentaries which does is a vivid and detailed description of a bush burn in the 1800s, by the pioneering Horowhenu settler (and later Palmerston North resident) Helen Wilson:

Sometimes, leaving unburnt patches behind, the flames leap half a chain ahead and, scampering madly up the trunk of a standing tree, seize on its foliage with vicious crackling and spluttering. When some succulent growth is exploded by the heat a shriek so human pierces the air that one's heart stands still until it fades into the reassuring hiss of escaping sap. Nevertheless, we look about us apprehensively and 
move further back. The sun, hanging apparently just above the tree-tops, is reduced to the size of a blood-red shilling and sheds, not light, but a murky glow so unreal that it helps us in the grandeur of the holocaust almost to forget the myriad living creatures who are perishing in terror and agony. ${ }^{57}$

In looking back at the destruction of Manawatu's forests through burning, Bradfield (1962) offers not only some context, but also a suggestion that had other technologies been available at the time, perhaps more of the forest might have been saved:

It is only when you get out of your car and walk into the bush that you realize how dense it can be and also what a problem it presented to the early settlers. No wonder they were so ruthless, especially with fire which could do more in a day to clear areas needed for cropping and grass, than a dozen or more men could do in a month with axes. If only they had had bulldozers and other such heavy machinery, undoubtedly much of the bush we have lost would have been saved. ${ }^{58}$

\section{Voices for Forest Preservation - National and Regional}

Meanwhile, at a national level, there was growing disquiet about the rapid destruction of New Zealand's forests, both through wasteful milling and subsequent burning. In 1868, in what is considered the first conservation speech in New Zealand's Parliament, Thomas Potts urged his fellow members to make provision for the conservation of the Colony's forests. His call was not without support from fellow members, such as Julius Vogel, William Travers and Charles Heaphy. In his contribution to the debate, Travers made reference to 'indiscriminate burning' of the forests in Canterbury (in part for the purpose of renewing pasture on the adjacent runs), and how the burning of forest at the head of the Waimakariri and other rivers had led to increased flooding in the district. ${ }^{59}$

These concerns eventually led to the passing of the first legislation regulating forestry in 1874. The New Zealand Forests Bill was introduced by Vogel, and its central intent was to encourage 'wise use' of timber by setting aside areas of State Forest. However, it was enacted in a much-diluted form, and only limited progress was made to set aside forest land. ${ }^{60}$ In 1877 , a new Land Act was passed, which enabled the Governor to declare forest reserves, and regulate their use. ${ }^{61}$ By 1881 , over half a million acres had been set aside under the Land Act for the 'growth and preservation of timber' or 'climatic forest conservancy', though little effort was given to managing these or other Crown forest lands. ${ }^{62}$ It is interesting to note that in percentage terms larger amounts of forest were reserved in the regions where forest was comparatively scarce. Thus, about half of the remaining forests in the Hawkes' Bay, 40 per cent in Marlborough, and just under 20 per cent in Canterbury was reserved, while in the Wellington Land District (which included the Manawatu), only 11 per cent was reserved. ${ }^{63}$

Under the $1885 \mathrm{New}$ Zealand State Forest Act, new mountain reserves were established to protect rivers, streams and 'climate', and new regulations were imposed on loggers and sawmillers. The Chief Conservator of Forests, Thomas Kirk, insisted that the boundaries of state forests be marked before adjoining land was sold, and imposed penalties for the destruction or damage of the forests by fire, felling or grazing. ${ }^{64}$ Progress was slow in achieving the objectives of the Act, partly owing to the prevailing view that development and economic growth should take priority over forest conservation, but also because of the conflict of interest inherent in the administration of the Act itself. The establishment and management of state forests remained under the general administration of the Lands Department, for which forest and land clearance, and the settlement of land for agriculture were central functions. ${ }^{65}$

Nevertheless, the protective importance of indigenous forests was recognized under the Act, and by 1909, two million acres of forest had been designated as state forest. Few reserves were designated in the Manawatu (by 1909, there had only 5,000 acres of Crown forest 
designated in a region encompassing the Manawatu, Horowhenua and northern Kapiti). ${ }^{66}$ One of the more significant of these reserves was what became known as the Totara Reserve, in the Pohangina Valley. Totara was a much prized timber - as a building timber, as well as for telegraph poles, posts and shingles - but had become depleted in many regions of New Zealand by the time the Chief Conservator of Forests, Thomas Kirk, travelled the country surveying the state of indigenous forests for his 1886 report to Parliament. ${ }^{67}$ Therefore it is not surprising that in 1886 this area of forest, known for its plentiful totara, was set aside as a forest reserve under the Act as a 'reserve for growth \& preservation of timber and for river conservation purposes'. The dual purpose of the reserve was underpinned by the growing realization that timber was becoming a limited resource, but also reflected a growing concern that deforestation was contributing to droughts and downstream flooding. ${ }^{68}$

In parallel with this utilitarian motivation for preserving indigenous forest, there was a growing emphasis on the scenic value of natural landscapes, and this came to be recognized officially under the 1892 Land Act, (and later the Scenic Preservation Act 1908), which allowed for the reservation of land for its scenic value. Under the Land Act, three million acres of land had been designated by 1907, primarily as national park. However, much of this was montane forest - very little was lowland forest. This reflected the prevailing reluctance to set aside forested land that was otherwise valuable for its millable timber - most forest in national parks designated under the Act was too steep and inaccessible for milling to be viable.

While these legislative developments were undoubtedly positive steps towards the preservation of some of New Zealand's forest resources, they all related to the designation and management of forests under the jurisdiction of the state. None dealt with the destruction of forest on private land. The Government only empowered itself (under the $1885 \mathrm{Act}$ ) to sanction a private landowner for causing damage to forest (by burning, felling or grazing) on adjacent state forestland. Not until a century later, under the Resource Management Act 1991, did it become possible for Government to regulate how landowners managed indigenous forest on their own land, and even then, only when it is deemed as 'significant' on a national or regional scale.

Roche (1987) observes that, outside Parliament, proponents of stronger indigenous forestry policy were predominantly 'atypical in being educated and wealthy and sufficiently insulated from the privations of a frontier existence' to be able to support such measures as embodied in the 1874, and later, 1885 Acts. ${ }^{69}$ Unfortunately, the paucity of written sources revealing the range of contemporary attitudes towards forest exploitation and conservation makes it difficult to test this assertion in the Manawatu context. However, a survey of Manawatu newspapers between the mid-1870s and the late 1880s does reveal a body of editorial comment concerning the need for forest conservation, and although an extremely limited source of evidence, it does hint at there being an element of this pattern in the Manawatu. Its limited nature is perhaps in itself telling of the priority (or otherwise) with which this issue was regarded in the district.

In the period between 1877 (when the first Manawatu paper was founded) and 1886 (a year after the State Forests Act was enacted), 16 articles relate to 'forest conservation', but of these only the Manawatu Standard offers any editorial comment, the others simply reporting on events or reprinting articles published in other papers. From 1883 (when the Manawatu Standard was founded) through to 1885 , the paper published a series of editorials, castigating the Government for its lack of progress on forest conservation and urging it to do more. For example, an editorial in August 1883 concluded: 'In comparison [with other countries] how criminal is the negligence displayed by our New Zealand Government in the matter of State forest conservation. ${ }^{70}$ Two months later, a further editorial lamented:

Last [Parliamentary] session saw no steps taken with regard to forest conservation, a fact which will be generally deplored. The opinion seems to be adopted that our 
forests will last for ever. The woods are disappearing from New Zealand by reason of the needs of settlement, and also by uncalled-for, wanton destruction, and now-adays too, by the large export of the timber to the great Australian cities which having used up their own forests and those of Tasmania, now look to other quarters for the supply. ${ }^{71}$

The following year, another Manawatu Standard editorial lamented that 'the splendid native forests which once covered a large portion of these islands are rapidly shrinking and in some parts disappearing before the destructive attacks of axe and saw, and the still more widely destructive inroads of fire. At the present rate of demolition, a few years will see New Zealand within measurable distance of being timberless, so far as the indigenous woods are concerned' ${ }^{72}$

As the New Zealand State Forest Bill was introduced in 1885 to be considered by Parliament, a further editorial in the Manawatu Standard urged passage of the Act; 'We trust the question will receive that earnest and practical consideration at the hands of the Legislature which its importance demands, and which it should have received some years ago.' Interestingly, in contrast to earlier editorials, which urged afforestation with fast-growing exotic species, this article criticizes the Government for that policy:

Government [sic] go to great expense in encouraging the planting of trees, while our grand forests of totara, kauri, red and black pine, kawaka, and many more which cannot be replaced for half a century, are being destroyed. The management of our forests needs a special Act to be made for them. Thousands upon thousands of pounds worth of timber is destroyed annually by wantonness or carelessness, and apparently in ignorance of its value. Of the immense tracts of magnificent timber what care is taken of it from being ruthlessly destroyed. ${ }^{73}$

It is only possible to speculate as to why forest conservation and forest policy received substantial editorial attention in the Manawatu Standard, and only cursory (predominantly non-editorial) coverage in the other Manawatu papers. However, it is likely that it relates to the values and beliefs of the editor at the time, Irishman Alexander McMinn. McMinn was the well-educated son of a doctor, who had originally come to New Zealand to cover the so-called 'New Zealand Wars' for a London newspaper. An erstwhile teacher/educator, he had returned to journalism at the New Zealand Herald, owned by (later Liberal Premier) John Ballance, with whom he developed a strong collegial friendship. McMinn was clearly a politically engaged and independent thinker, quite comfortable expressing an opinion on matters that may have put him at odds with general thinking in his local community at the time.

The situation in the Manawatu was coming to the attention of officials and academics outside the district too. In its 1909 report on forestry in New Zealand, the Department of Lands cited J.P. Grossman's monograph 'Deforestation and its consequences' (1909) at some length. Grossman warned that 'the reckless slaughter of forests' in New Zealand would lead to similar consequences as those experienced in America: floods, soil erosion, and the concomitant loss in farm production. ${ }^{74}$ While Grossman was an Aucklander (an academic at Auckland University College), he wrote about the effects of deforestation in the Manawatu district and surrounding districts in some detail:

So far as New Zealand is concerned, the country is still too young to have experienced the worst effects of deforestation either in regard to erosion or floods. But, even as it is, it is no exaggeration to say that there is not a single district in the Dominion in which the native bush has been cleared away round the head-waters of the rivers that does not exhibit some of the disastrous consequences above described [in America] ... Some years ago Mr. R.W. Holmes, now Engineer-in-Chief to the Public Works 
Department, reported to the Feilding Borough Council on a serious washout at the junction of the Oroua and Kiwitea Rivers, involving the loss of over 50 acres of valuable land, and he attributed this disastrous flood entirely to the destruction of the bush along the upper courses of the rivers. Throughout the Wellington and Wanganui Districts the same tale can be told ... wherever the bush around the sources of streams has been cut away, floods of varying degrees of intensity and destructiveness have inevitably followed. ${ }^{75}$

While this survey of commentary on both bush burning and forest destruction, and policy more generally, is a limited one, it does lend support to the proposition that it tended to be the wealthy, the well-educated and those sufficiently insulated from the difficulties of pioneering life, who expressed a dissenting view of forest destruction or were proponents of stronger forest conservation policy. Even so, the Manawatu is notable in the lack of politically engaged forest conservation advocates. Any critical view expressed appears to have been predominantly from the comfort of the editorial desk, or with the benefit of hindsight, commenting on the lamentable (but irreversible) loss of forest. This contrasts with other regions, particularly in the South Island, where a number of prominent individuals advocated for the preservation of indigenous forest. These included the Deans family who in the mid-1800s preserved a large area of forest in Christchurch; Thomas Potts (1824-1888), who complained of the 'barbarous improvidence' of contemporary attitudes towards the forest, and Harry Ell, (1862-1934), both of Christchurch; William Travers (1819-1903) of Nelson/Christchurch and Leonard Cockayne (1855-1934), of Christchurch/Wellington. Later, Hawkes' Bay farmer, naturalist and writer William Herbert Guthrie-Smith (1862-1940) added his voice to the growing sense of doubt about the prevailing doctrine of progress, when he lamented, in respect to his own sheep station, 'Have I then, for sixty years desecrated God's earth and dubbed it improvement?'

Compared to the Manawatu, the early settlements of Canterbury, Otago, and to some extent, Nelson, attracted wealthier immigrants from more highly educated backgrounds. In comparison, the Manawatu by and large attracted immigrants of modest means, whose object in coming to New Zealand was to own their own land, something they would be unlikely to achieve if they remained in their country of birth. For these people, the forest simply posed a barrier to achieving this objective. As Wynn points out in his 1977 essay, in relation to the wider response to the 1874 New Zealand Forests Bill:

For them, exploitation of the New Zealand forest was a constructive rather than a destructive process; it yielded important export revenues and enhanced the value of the country by converting 'waste lands''into a 'higher' use as farm ... It was futile to describe forest conservation to settlers of the bush as a measure catering to the welfare of posterity. Engaged in a struggle of such magnitude and immediacy, they could neither conceive of the exhaustibility of the timber supply, nor believe that their efforts to provide a competency for their own and their children's children might impoverish the future. ${ }^{77}$

The difference in concern is also likely to relate to geographical factors. When the first European settlers arrived in Canterbury, Otago, Marlborough and Hawkes' Bay, much of the forest had already gone, and what was left was valued more than it was in heavily forested districts such as the Manawatu. In his contribution to the 1868 Parliamentary debate on forest preservation, Edward Stafford (member for Nelson and former Premier), observed this regional variation in attitudes: '.. settlers, where little timber existed, were impressed from the first with the idea of planting trees; whereas, when settlers found themselves in the middle of a forest, the primary idea with them and their children was to destroy the timber'. ${ }^{78}$ It is likely that for this reason, the Deans' brothers, who were the first European settlers of Christchurch, 
were determined to preserve the forest of Putaringamotu (a remnant of which still remains today as Riccarton Bush), a decision probably also influenced by the fact that lowland forest was so rare and contested in their native Scotland. In contrast, in the Manawatu, the largest remnant of lowland forest, now called Totara Reserve, was reserved by the Government for its valuable timber (which was selectively cut out), rather than for its intrinsic value or even for 'future use'. Nevertheless, this was vastly closer to 'wise use' than the model that was applied more broadly across the Manawatu - the 'improvement' of land through the wholesale destruction of its forest cover.

\section{Conclusions: Why was the Destruction of Manawatu's Forest So Rapid?}

When its European settlement began in the late 1860s, most of the forest of inland Manawatu and indeed, the south of the North Island, was intact. However, by 1905, most of the North Island's lowland forest had gone; swept away through two phases of destruction, first by milling and then by the fires of the bush farmer. This wave of destruction was swift, in the most part happening within three decades. Though regretted by some, it was viewed with a resigned acceptance by most. If questioned at all, it was generally from a perspective of utilitarianism, that the destruction of the forest without any afforestation would fail to provide for future timber needs.

However, unlike other regions, particularly the South Island, there was no evidence of serious protestation against the assault on the forest, and certainly none that led to any attempts to conserve lowland forest. Two reasons are posited for this. The first relates to the type of settler that was attracted to the Manawatu. Generally these were from a working-class background, willing to undertake many years of hard labour to 'break in' a bush farm. This work was seen as the means by which they would become self-supporting, independent landowners - something that they, or their fathers, were unlikely to have achieved in Britain or Europe. For these settlers, the destruction of the forest represented progress, and took them closer to this goal. Having little capital to invest in their fledgling farming enterprise, they needed to use methods that were both cheap and efficient, even if their consequences were detrimental in the long term. When concerns were raised about the rate of forest destruction, both in the Manawatu, and elsewhere, it was generally the well-educated town-dweller or wealthier landowner who raised these concerns. Arguably, these people were insulated from the harsh reality of being compelled to destroy the forest to make a living from the land. ${ }^{79}$

However, a second factor is likely to be an environmental one: the Manawatu, and neighbouring districts such as Taranaki and western Hawkes' Bay were almost entirely forestcovered when their settlement began. The forest would have appeared limitless - a colossal barrier between the settler and 'progress'. But in Canterbury and Otago, lowland forest was already a rare commodity by the time of European settlement. For this reason, some of its earliest settlers advocated for forest conservation, or (in the case of the Dean's brothers) made a personal commitment to preserve the forest. In the Manawatu, numerous landowners preserved small areas of bush on their property, either for sentimental reasons or for practical ones. Some of these remnants survive today, but being small and isolated are generally degraded by grazing, possum damage, wind damage or (in the case of wetland forest) a receding water table. Sadly, from the perspective of today's inhabitants of the region, individuals willing to advocate for forest preservation on a larger scale were either absent or unsuccessful, and Manawatu residents can now only imagine the 'sylvian giants' of the forest that covered the hills, valleys and plains of the region more than a century ago. 


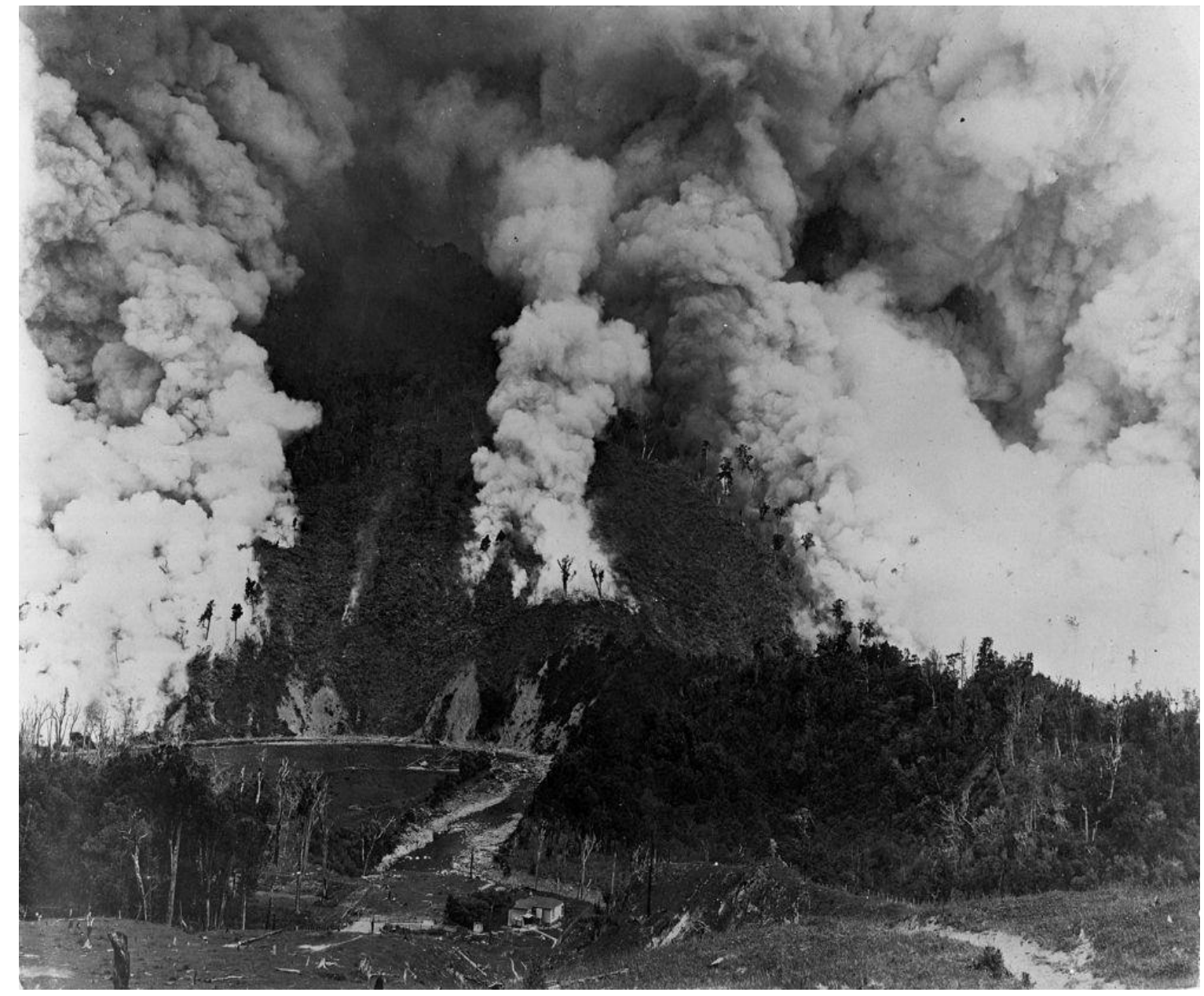

Figure 6: The start of a 30,000 acre fire, lit to clear the land of bush. Alexander Turnbull Library, Frederick Ashby Hargreaves Collection. 
${ }^{1}$ Semi-swamp forest dominated by kahikatea and pukatea grew on the low-lying land near rivers, totara and podocarp-broadleaf forest covered much of the plains and terrace-lands, and tawa-dominant forest characterized the greywacke hills. A. E. Esler, Botany of the Manawatu District of New Zealand (Wellington: E.C. Keating, Govt. Printer, 1978), 26.

${ }^{2}$ A Foxton to Palmerston tramway (horse-drawn) as completed in 1874, and was converted to a railway in 1876. This was then extended to Wanganui in 1878.

${ }^{3}$ Grain-growing was largely confined to the ‘open country' of north-west Manawatu - Oroua and Sandon (Sanson) areas, rather than the bush country.

${ }^{4}$ Alan Gray, Aotearoa and New Zealand - a Historical Geography (Christchurch: Canterbury University Press, 1994), 281.

${ }^{5}$ Malcolm McKinnon, ed., New Zealand Historical Atlas - Ko Papatuanuku e Takoto Nei (Auckland: Bateman, 1997), plate 47.

${ }^{6}$ For a discussion of the environmental consequences of deforestation in this region, see Catherine Knight, 'The Paradox of Discourse Concerning Deforestation in New Zealand: A Historical Survey', Environment and History 15 (2009): 323-342.

${ }^{7}$ Ian Matheson, 'The Birth of Palmerston North', Evening Standard Centenary Supplement, Manawatu Evening Standard, 1971, 52-3.

${ }^{8}$ These areas had originally been forested, but the forest had been destroyed - most likely by fire - during preEuropean times. When Europeans began settling New Zealand in the nineteenth- century, these regions were covered in scrub or tussock, with areas of forest, in valleys and other places that successive fires had not reached. Owing to their relative 'openness', they were unsurprisingly attractive to the early settler.

${ }^{9}$ This policy manifested itself in particular through the Land Act of 1877 and its 1885 amendment, which encouraged the settlement of land by those of lesser means. In addition to the provision for deferred payment, the 1877 Act set the maximum size of land that could be purchased at 320 acres (130 hectares), and excluded those who already owned 640 acres (260 hectares). The 1885 Act allowed settler associations to establish special settlements of smaller farms on deferred payment or perpetual lease. It also created a class of small grazing runs of up to 5,000 acres (2,023 hectares) that could be leased by smaller sheep farmers. Rent was only $2.5 \%$ of the value and, since the land was often rough bush country worth only about five shillings an acre, farmers were charged extremely low rents so they could put their money into stock and improvements. See Jim McAloon, 'Land ownership - Centralisation after 1870', Te Ara - the Encyclopedia of New Zealand, 13 July 2012, http://www.TeAra.govt.nz/en/land-ownership/page-4, accessed 25 July 2012.

${ }^{10}$ Indeed, it was on the policy platform of breaking up the great estates that the Liberal government was elected in 1890. In the South Island, between 1891 and 1912, the Government bought 1,296,942 acres (524,800 hectares) from 223 estates. In the North Island 2.3 million acres (930,000 hectares) of Māori land were purchased for European settlers. Hugh Stringleman and Robert Peden, 'Sheep farming - The refrigerated meat trade', Te Ara - the Encyclopedia of New Zealand, 13 July 2012, http://www.TeAra.govt.nz/en/sheepfarming/page-5, accessed 30 July 2012.

${ }^{11}$ Influenced by a landmark Supreme Court ruling in the mid 1880s, the Government viewed all land not cultivated by Māori as 'waste land' that reverted to the Crown. Governor George Grey encouraged mass purchase of Māori land, and Māori were advised to gain Crown title. Jim McAloon, 'Land ownership - Māori and land ownership', Te Ara - the Encyclopedia of New Zealand, 13 July 2012,

http://www.TeAra.govt.nz/en/land-ownership/1, accessed 22 July 2012.

${ }^{12}$ Raeburn Lange, The Social Impact of Colonisation and Land Loss on the Iwi of the Rangitikei, Manawatu and Horowhenua Region, 1840 - 1960 (Wellington: Crown Forestry Rental Trust, 2000), 9-11.

13 The major newspapers covering the decades during which bush burning was prevalent were: The Feilding Star (1882 - 1920), Manawatu Herald (1878 - 1900), Manawatu Standard (1883-1905) and the Manawatu Times (1877-1905). Information is therefore limited by the date range of these papers, the first of these not being established until 1877. The Wanganui Chronicle, established in 1874, and the Wanganui Herald, established in 1867, did cover news from the newly established town of Palmerston, but little appears regarding bush clearance around the town before the mid-1870s. Early reports from the Wellington Independent (1845-1874) do not appear to refer to bush clearance. All newspaper articles accessed through Papers Past

(paperspast.natlib.govt.nz).

${ }^{14}$ Feilding Star, 11 July 1906, 4.

15 The Feilding Star reported that a number of settlers in Apiti had undertaken burns in the summer of 1897, for example Feilding Star, 29 December 1897, 2.

${ }^{16}$ A.G.S. Bradfield, Forgotten Days: Pioneering Experiences of the Early Citizens of Palmerston North and settlers of the Manawatu (Levin: Kerslake, Billens and Humphrey Ltd, 1956), 53. 
${ }^{17}$ The deposit was one-tenth of the price (purchasers in the Kairanga Block, west of Palmerston North, were required only to pay five per cent), and the balance could be repaid over ten years. See McAloon, 'Land ownership - Centralisation after 1870', and Richard Mildon, Kairanga: more than one hundred years (Waikanae: Heritage Press 1989), 21.

${ }^{18}$ The average size of a sheep farm today is 443 hectares, while the average size of a sheep-beef cattle farm is 679 hectares. The average size of a dairy cattle farm is 172 hectares. See 'Average New Zealand Farm Size by Farm Type', Land Information New Zealand, http: www.linz.govt.nz, accessed 1 August 2012.

${ }^{19}$ Mildon, Kairanga: more than one hundred years, 37-8.

${ }^{20}$ Timaru Herald, 4 September 1891, 3.

${ }^{21}$ Matheson, 'The Birth of Palmerston North', 52-3.

${ }^{22}$ Ibid.; D. Thomas Waugh, North to Kimbolton (Feilding: Fisher Print, 1986),15.

${ }^{23}$ Feilding Star, 13 August 1891, 4. 'Slumicking' does not appear to be a widely used expression. The present author was unable to find any other references to the term, either in newspaper articles or the literature.

${ }^{24}$ Feilding Star, 17 March 1891, 3; Feilding Star, 19 March 1891, 2. The Feilding-based Bush Fellers Union, established in 1890, was short-lived, disbanding after only a year. This was apparently due to the inability to settle on uniform rates for underscrubbing and bushfelling, owing to the great variety of bush types, and therefore the level of effort required. See Timaru Herald, 4 September 1891, 3.

${ }^{25}$ Manawatu Standard, 2 January 1885, 2.

${ }^{26}$ Manawatu Standard, 8 January 1885, 3.

${ }^{27}$ Feilding Star, 12 March 1891, 2.

${ }^{28}$ Manawatu Times, 28 March 1883, 2.

${ }^{29}$ Feilding Star, 17 December 1889, 2.

${ }^{30}$ Rollo Arnold, New Zealand's Burning: The Settlers' World in the Mid 1880s (Wellington: Victoria University Press, 1994).

${ }^{31}$ Notifying neighbours of a planned bush burn was not only seen as a common courtesy, it was also important to enable them to take precautionary measures to mitigate the risk of the fire spreading to their own properties.

${ }^{32}$ Manawatu Standard, 3 February 1885, 3.

${ }^{33}$ Feilding Star, 11 February 1888, 2.

${ }^{34}$ Feilding Star, 6 February 1892, 2; Manawatu Standard, 18 December 1900, 4; Arnold, New Zealand's Burning, 84.

${ }^{35}$ Feilding Star, 6 January 1897, 2.

${ }^{36}$ Feilding Star, 18 February 1892, 2.

${ }^{37}$ Matheson, 'The Birth of Palmerston North, 54-5.

${ }^{38}$ Mildon, Kairanga, 46.

${ }^{39}$ See for example, Feilding Star, 18 February 1892, 2 and 10 March 1892, 2. This flush of growth proved only temporary, however. After a few seasons, pasture would often become weed-infested and farmers had to look toward 'artificial manures' (fertilizers) such as lime, and later superphosphate, to promote pasture growth.

${ }^{40}$ Matheson, 'The Birth of Palmerston North', 52-3; Charlotte Eliot Warburton, Changing Days and Changing Ways (Palmerston North: Keeling \& Mundy Ltd, 1954), 86.

${ }^{41}$ Matheson, 'The Birth of Palmerston North', 54-5.

${ }^{42}$ Robert Peden, 'Fire and agriculture - North Island farms: bush and fern', Te Ara - the Encyclopedia of New Zealand, 13 July 2012, http://www.TeAra.govt.nz/en/fire-and-agriculture/3, accessed 20 July 2012.

${ }^{43}$ Matheson, 'The Birth of Palmerston North', 55.

${ }^{44}$ Feilding Star, 3 December 1903, 2.

${ }^{45}$ Manawatu Times, 14 March 1877, 2.

${ }^{46}$ Manawatu Times, 19 March 1879, 2.

${ }^{47}$ Manawatu Standard, 27 February 1886, 2.

${ }^{48}$ Bradfield, Forgotten Days, 53.

${ }^{49}$ Manawatu Herald, 14 March 1891, 2.

${ }^{50}$ Feilding Star, 17 January 1898, 2.

${ }^{51}$ Feilding Star, 5 April 1897, 2.

${ }^{52}$ Manawatu Herald, 5 March 1889, 2.

${ }^{53}$ Feilding Star, 23 December 1890, 3.

${ }^{54}$ T. L. Buick, Old Manawatu (Palmerston North: Buick \& Young, 1903), 119.

${ }^{55}$ Bradfield, Forgotten Days, 68.

${ }^{56}$ Warburton, Changing Days and Changing Ways, 56.

${ }^{57}$ Helen Wilson, My First Eighty Years (Hamilton: Paul's Book Arcade, 1951), 130.

${ }^{58}$ A. G. S. Bradfield, The Precious Years: Further Stories of the Pioneering Days of Palmerston North and

Districts in the Manawatu (Levin: Kerslake, Billens and Humphrey Ltd, 1962), 63. 
${ }^{59}$ Appendices to the Journals of the House of Representatives (AJHR), 1874, I-H-05, 4. The 'indiscriminate' nature of the burning of these Canterbury runs has since been disputed, most recently by Robert Peden, 'Pastoralism and the Transformation of Open Grasslands', in T. Brooking, and E. Pawson, eds, Seeds of Empire: The Environmental Transformation of New Zealand (London/New York: L.B. Tauris, 2010), 73-93.

${ }^{60}$ M.M. Roche, Forest Policy in New Zealand: an historical geography, 1840-1919 (Palmerston North:

Dunmore Press, 1987), 86-90.

${ }^{61}$ Roche, Forest Policy in New Zealand, 92.

${ }^{62}$ Graeme Wynn, 'Destruction Under the Guise of Improvement? The Forest, 1840 - 1920', in E. Pawson and T. Brooking, eds, Environmental Histories of New Zealand (Oxford/New York: Oxford University Press, 2002), 113.

${ }^{63}$ Roche, Forest Policy in New Zealand, 92.

${ }^{64}$ Wynn, 'Destruction Under the Guise of Improvement?', 113.

${ }^{65}$ A.H. McLintock, ed., 'Early Forest Legislation', in An Encyclopaedia of New Zealand (originally published in 1966), http://www.teara.govt.nz/en/1966/forestry/3, accessed 5 July 2012.

${ }^{66}$ AJHR, 1909, II-C-04, 35. On these Crown forest lands, the estimated volumes of millable timber were (in superficial feet): totara, 34,000,000 superficial feet; matai, 11,000,000; rimu and miro, 10,000,000; kahikatea, $13,000,000$.

${ }^{67}$ AJHR, 1886, I-C-03a.

${ }^{68}$ Catherine Knight, 'Totara Reserve: A Window into Manawatu's Environmental History', Manawatu Journal of History, 4 (2008), 50-58. Today, Totara Reserve is valued as a recreational reserve and as a haven for increasingly rare lowland biodiversity. However, a reminder of its original purpose as a source of timber is manifestly apparent in the huge totara stumps scattered throughout the forest: indeed, most of the large totara in the reserve had been milled by the time the reserve became a public domain in 1947.

${ }^{69}$ Roche, Forest Policy in New Zealand, 88.

${ }^{70}$ Manawatu Standard, 6 August 1883, 2.

${ }^{71}$ Manawatu Standard, 5 October 1883, 2.

${ }^{72}$ Manawatu Standard, 31 March 1884, 2.

${ }^{73}$ Manawatu Standard, 6 June 1885, 2.

${ }^{74}$ AJHR, 1909, II-C-04, 95.

${ }^{75}$ Ibid.

${ }^{76}$ For a discussion of such dissenting views see Wynn, 'Destruction Under the Guise of Improvement?',111112.

${ }^{77}$ Graeme Wynn, 'Conservation and Society in late nineteenth-century New Zealand', New Zealand Journal of History, 11, 1, (1977):135.

${ }^{78}$ AJHR, 1874, I-H-05, 3.

${ }^{79}$ Geoff Wilson comes to a similar conclusion in his study of farming settlers' attitudes to bush burning in the Catlins District of the lower South Island. Like the Manawatu (and unlike much of the eastern South Island) this area was thickly forested, and attracted many settlers of lesser means. As was the case in the Manawatu, Wilson's study found that while these early pioneers were not without an aesthetic appreciation of the indigenous forest, any such appreciation was overshadowed by the economic imperative to clear the bush. See Geoff A. Wilson, 'A Study of Native Forest Clearance on Farms in the Catlins District of New Zealand, 18611990’, Studies in Rural Change, 18 (1992). 